\title{
Management of haemorrhagic enteritis in a striped hyena (hyaena hyaena): a case report
}

\begin{abstract}
A case of severe 'Haemorrhagic enteritis' was reported in a striped hyena (Hyaena hyaena) at Nandankanan Zoological Park, Odisha, India. The clinical signs, haematological parameters, serum biochemistry showed similarity to a viral infection like 'Canine Parvovirus infection (CPV)'. The hyena was under regular vaccination against CPV using multivalent vaccine meant for domestic dogs. Though the etiological agent behind such acute Haemorrhagic enteritis and leukopaenia could not be isolated with the available laboratory facilities, the striped hyena was successfully treated due to early detection of sickness, prompt and aggressive treatment.
\end{abstract}

Keywords: striped hyena, haemorrhagic enteritis, leukopaenia, canine parvovirus infection, EDTA
Volume 3 Issue I - 2018

\author{
Sarat Kumar Sahu,' Niranjan Sahoo, ${ }^{2}$ Rajesh \\ Kumar Mohapatra' \\ 'Nandankanan Zoological Park, Odisha, India \\ ${ }^{2}$ College of Veterinary Science and Animal Husbandry, OUAT, \\ Odisha, India
}

Correspondence: Rajesh Kumar Mohapatra, Nandankanan Zoological Park, Odisha, India, Tel +9I-9937563742,

Email rajesh.wildlife@gmail.com

Received: December 14, 2017 | Published: February 06, 2018

\section{Introduction}

Striped hyenas (Hyaena hyaena) are carnivorous mammals belonging to the family Hyaenidae having a wide distributional range including Indian subcontinent. ${ }^{1,2}$ Information on the disease and healthcare management of striped hyenas is inadequate and inconsistent. Hyenids are susceptible to the same diseases as canids and felids and are diagnosed and treated similarly. ${ }^{3,4}$ Shedding of Feline panleukopenia virus was reported in fecal samples of three striped hyenas of Nandankanan Zoological Park, Odisha, India. ${ }^{5}$ Reports on incidences of contagious diseases in striped hyenas are scarce, though it is not an uncommon species in Indian zoos. The present paper reports an incidence of haemorrhagic enteritis in a striped hyena in captivity at Nandankanan Zoological Park, Odisha, India.

\section{Case history and observation}

A three year old female striped hyena was housed in an open air enclosure of 50 square meter floor area with another male striped hyena of the same age. On 12.02.2014, it was observed being dull, depressed and lethargic. Upon close examination, the hyena was found with dark tarry colour foul smelling watery diarrhoea, in coordinated gait, staring look, pale buccal mucosa and dehydration. The affected hyena was immediately segregated on physical restraint. At the time of examination, animal showed pain on pressing the abdomen and stomach. The rectal temperature, respiration rate and pulse rate were recorded to be $103{ }^{\circ} \mathrm{F}, 24$ per minute and 126 per minute respectively. It was shifted to 'Isolation Ward' of Zoo Hospital, Nandankanan for intensive monitoring, care and treatment.

\section{Treatment with management}

Hemorrhagic enteritis is an acute, severe form of diarrhea that warrants immediate intensive therapy. Considering the need, round the clock monitoring of the animal was carried out through CCTV cameras along with aggressive treatment. Vital signs such as heart rate, respiration, urination and body temperature were monitored regularly. As the hyena was dull, it could be handled with minimum physical restraint inside squeeze cage. The body weight of the hyena was $22 \mathrm{~kg}$. Blood samples were collected in EDTA and Fluoride before and after treatment to study the haematological parameters. Besides, the blood samples for the presence of haemoprotozoan parasites and the fecal sample for the presence of helminth parasites were screened. Food for the hyena was withheld for 24 hours in order to give rest to its stomach. The hyena was treated with administration of intravenous fluid, $200 \mathrm{ml}$ each of Normal saline, Dextrose $5 \%$ and Ringer's Lactate (Claris Life Sciences Limited, Ahmadabad, India) twice daily. Along with the fluids $45.5 \mathrm{mg}$ pheniramine maleate (Avilin, MSD-Animal Health, 33, Pune-Nagar Road, Viman Nagar, Pune, India) intramuscularly and, Ranitidine@0.5mg/kg IV, Antibiotic Ceftazidime@25mg/kg (Fortum, GlaxoSmithKline, Dr. Annie Besant Road, Mumbai, India) intravenously at $12 \mathrm{hr}$ interval and Amikacin@10mg/kg (Mikacin, Aristo Pharmaceuticals, Shah Industrial Estate, Andheri West, Mumbai, India) intravenously at $12 \mathrm{hr}$ interval were given to prevent the secondary bacterial infection. This treatment regime continued for three days. As a supportive therapy B-complex inj (Conciplex, Concept Pharmaceuticals ltd, Andheri East, Mumbai, India) was administered intravenously along with fluid. Colour and consistency of faeces changed to normal in three days and the animal regained its full appetite in a week. Results of hematological parameters before and after treatment and examination of fecal sample of the hyena is given (Table 1).

Table I Hematological and fecal sample examination of the striped hyena (Hyaena hyaena)

\begin{tabular}{lll} 
Parameters & $\begin{array}{l}\text { Parameters before } \\
\text { treatment }\end{array}$ & $\begin{array}{l}\text { Parameter on } 3^{\text {rd }} \\
\text { day of treatment }\end{array}$ \\
\hline $\mathrm{Hb}(\mathrm{gm} \%)$ & $8.00 \mathrm{gm} \%$ & $10.2 \mathrm{gm} \%$ \\
$\mathrm{PCV}$ & $31 \%$ & $42 \%$ \\
$\begin{array}{l}\text { Platelets (in lakhs)/ } \\
\text { cumm }\end{array}$ & 0.9 & 2.5 \\
TLC/cumm & 3700 & 6100 \\
Neutrophils (in \%) & 40 & 69 \\
Lymphocyte (in \%) & 60 & 27 \\
Monocyte (in \%) & -- & 2 \\
Eosinphil (in \%) & -- & 2 \\
Basophil (in \%) & -- & -- \\
\hline
\end{tabular}


Table Continued....

\begin{tabular}{lll}
\hline Parameters & $\begin{array}{l}\text { Parameters before } \\
\text { treatment }\end{array}$ & $\begin{array}{l}\text { Parameter on } 3^{\text {rd }} \\
\text { day of treatment }\end{array}$ \\
\hline Glucose $(\mathrm{gm} / \mathrm{dl})$ & 56 & 80 \\
Haemoprotozoan & NIL & NIL \\
$\begin{array}{l}\text { Fecal sample } \\
\text { examination }\end{array}$ & $\begin{array}{l}\text { Negative for parasitic } \\
\text { ova }\end{array}$ & $\begin{array}{l}\text { Negative for parasitic } \\
\text { ova }\end{array}$ \\
\hline
\end{tabular}

\section{Discussion}

Such type of Haemorrhagic enteritis, in dog are reported due to several etiologies such as Parvo virus infection, ${ }^{6-9}$ Corona virus, ${ }^{10}$ Rota virus, ${ }^{11}$ bacterial infections like Escherichia coli or Clostridium spp, ${ }^{11}$ endoparasites such as Strongyloides stercoralis, Ancylostoma caninum ${ }^{12}$ and Haemorrhagic gastro-enteritis syndrome. ${ }^{13}$ In this case the blood sample was found negative for haemoprotozoan parasites and fecal sample was found negative for helminth parasites. The clinical signs such as elevated body temperature, heart rate and respiration rate, paleness of mucous membrane, bloody diarrhoea, lethargy, anorexia and dehydration were also reported in canine parvovirus (CPV) infection in dogs. ${ }^{14}$ But haematemesis, reported in parvovirus infection in dogs, is not found in this case. The haematological parameters showing leukopenia (TLC count 3700/cumm), increase in lymphocyte count $(60 \%)$ and decrease in Neutrophil count $(40 \%)$ are suggestive of viremia. This indicates that this condition in hyena was detected in early stage. Such lymphocytosis in early stage was also recorded in dogs, which might be due to parvovirus replication in the lymphoid organ in the early stage. ${ }^{15,16}$ A significant decrease in Haemoglobin concentration (8gm\%) and PCV (31\%) corroborates with the findings in Parvo viral infection in dogs. ${ }^{17}$ There was also a significant decrease in blood glucose level to $56 \mathrm{gm} / \mathrm{dl}$ which may be due to anorexia. The clinical signs and haematological parameters (Table 1) improved during treatment which indicates positive response to treatment.

The above findings of clinical signs and haematological parameters are very much similar to a viral infection like 'parvovirus infection', but the etiological agent behind 'haemorrhagic enteritis' in this case, could not be isolated in laboratory with the available facilities. Further, this hyena was under regular vaccination against CPV using multivalent vaccine Nobivac $^{\circledR}$ DHPPi (MSD-Animal Health, 33, Pune-Nagar Road, Viman Nagar, Pune, India) meant for domestic dogs, following manufacturers' guideline. There are incidences of CPV outbreak in dogs, despite vaccination. An outbreak of canine parvovirus type $2 \mathrm{c}(\mathrm{CPV}-2 \mathrm{c})$ infection in vaccinated adult dogs was reported in a breeding Kennel in Italy those were repeatedly vaccinated using vaccines containing a type 2 (old type) CPV strain. ${ }^{18}$ Also, shedding of Feline panleukopenia virus (FPLV) in fecal samples of striped hyenas (Hyaena hyaena) was reported at Nandankanan Zoological Park, Odisha, India those were covered under vaccination with CPV strain. ${ }^{19}$

\section{Conclusion}

Though this hyena was successfully treated due to early detection of sickness, prompt and aggressive treatment, more investigations are required to find out the causative agent behind such acute haemorrhagic enteritis and leukopenia. With the advent of molecular technique attempt can be made to isolate the virus from clinical material like faecal sample so that the virus antigen can be included in the vaccine to protect our valuable wild animals like striped hyena.

\section{Acknowledgements \\ None.}

\section{Conflict of interest}

The author declares no conflict of interest.

\section{References}

1. Mohapatra RK, Sahu SK, Panda S. Perspectives in Animal Ecology and Reproduction. In: Gupta VK, Verma AK, et al. editors. Mating behaviour of striped hyena (Hyaena hyaena) in captivity. 10th ed. ASTRAL; 2015. p. 331-335.

2. Prater SH. The book of Indian animals. 3rd ed. India: Bombay Natural History Society; 2005. p. 103-110.

3. Fowler ME. Zoo and wild animal medicine. 2nd ed. USA: WB Saunders Co Philadelphia; 1986. p. 830-831.

4. Williams ES, Thorne ET. Infectious and parasitic diseases of captive carnivores, with special emphasis on the black-footed ferret (Mustela nigripes). Rev Sci Tech. 1996;15(1):91-114.

5. Kharate A, Panda HK, Panda SK, et al. Feline Panleukopenia in wild felines of Nandankanan Zoological Park, Odisha, India. Indian Journal of Veterinary Pathology. 2015;39(2):132-135.

6. Banja BK, Sahoo N, Das PK, et al. Clinicotherapeutic aspects of gastroenteritis in dogs. Indian Veterinary Journal. 2002;79:837-840.

7. Nandi S, Kumar M. Canine Parvovirus: Current Perspective. Indian J Virol. 2010;21(1):31-44.

8. Sahoo N, Parida GS, Sardar KK. Clinical sign based prognosis of canine parvovirus infection. Indian Veterinary Journal. 2007;84:637-638.

9. Toma B, Moraillon A. Infection of the dog by a corona virus antigenically related to porcine transmissible gastroenteritis virus. Collection of Veterinary Medicine. 1980;156:464-470.

10. Barrios M, Luya ML, Reyna A, et al. Isolation of parvovirus from a dog with haemorrhagic gastroenteritis in cuba. AGRIS. 1989;20:297-304.

11. Marks SL, Kather EJ. Bacterial-associated diarrhea in the dog:a critical appraisal. Veterinary Clinics of North America: Small Animal Practice. 2003;33(5):1029-1060.

12. Kumar S, Reddy KMP, Chaudhary PE. A rare case of mixed infestation of $D$ Caninum and A Caninum in Doberman dogs and its therapy. Vet Pract. 2001;2:57-58.

13. Kumar A, Singh Saini N, Bisht S. Treatment of Haemorrhagic gastroenteritis in dog. IJIRR. 2014;1(12):193-194.

14. Reddy KB, Shobhamani B, Sreedevi B, et al. Canine parvo viral infection in dogs and their treatment. Inter J Vet Sci. 2015;4(3):142-144.

15. Chakrabati A. A Textbook of Preventive Veterinary Medicine. 3 rd ed. India: Kalyani Publishers; 2003. p. 2812-3286.

16. Ramprabhu R, Pradhan S, Nambi AP, et al. Haemarrhagic gastro-enteritis in dogs-A clinical profile. Indian Veterinary Journal. 2002;79:374-376.

17. Kumar A, Kumar RK. Clinico-hematobiochemical changes in parvo viral infection in dog. International Journal of Science, Environment and Technology. 2017;6(5):2837-2841.

18. Decaro N, Desario C, Elia G, et al. Evidence for immunization failure in vaccinated adult dogs infected with canine parvovirus type 2c. New Microbiol. 2008;31(1):125-130.

19. Harrison TM, Mazet JK, Holekamp KE, et al. Antibodies to canine and feline viruses in spotted hyenas (Crocuta crocuta) in the Masai Mara National Reserve. Journal of Wildlife Diseases. 2004;40(1):1-10. 